\title{
Trade marks in Tanzania: the prima facie case and interim relief
}

\author{
Alex B. Makulilo*
}

Although the temporary injunction is a civil remedy, available in all types of proceedings, in Tanzania it is frequently refused in trade mark infringement disputes. High Court of Tanzania (HCT) case law indicates the difficulty the judges encounter in determining temporary injunctions without considering the merits of the main suit. This difficulty is in applying the first principle, i.e. a prima facie case with a probability of success. This article analyses the jurisprudence of the HCT and considers how the requirement of a prima facie case may be satisfied. Analysis of irreparable injury and balance of convenience, the second and third principles for determining temporary injunction, are beyond the purview of this review since they have caused no substantial problems.

Part one of this article introduces the problem presented by HCT case law covering applications for temporary injunctions in trade mark infringement disputes. Part two outlines conditions and principles that must be fulfilled for an order of temporary injunction to issue. Part three discusses the interaction between these requirements and the principles governing trade mark infringement. Part four analyses the case law itself and identifies the flaws in the Court's interpretation of prima facie case with a probability of success. Part five proposes a possible interpretation of the principle of prima facie case in the context of trade mark infringement disputes.

\section{Conditions and principles governing temporary injunctions}

The jurisdiction of the HCT to hear applications for temporary injunction is governed by section 68(c) and Order 37 Rules 1 and 2 of the Civil Procedure Code. ${ }^{1}$ Section 68(c) generally vests in courts jurisdiction to grant temporary injunctions. This jurisdiction may only be exercised under the circumstances laid down in Order 37 Rules 1 and 2 of the Code.

\footnotetext{
Assistant Lecturer of Law, Open University of Tanzania; advocate of the HCT. The author is a member and country expert for African Legal Research on Information and Communication Technologies (AFLRICT) and a member of freelance researchers at the Faculty of Law and Criminology at Virje Universiteit Brussels. He is a Deutscher
}

\section{Key issues}

- This article analyses case law developed by the High Court of Tanzania concerning the temporary injunction in trade mark infringement disputes.

- Analysis is limited to the principle of the 'prima facie case' as this appears to be the most difficult criterion to apply in the context of trade mark infringement disputes.

\section{Section 68(c) of the Civil Procedure Code}

Under section 68(c), in order to prevent the ends of justice from being defeated the court may, subject to any other rules, grant a temporary injunction and, in case of disobedience, commit the party in breach as a civil prisoner and order that his property be attached and sold.

The provision of section 68(c) has two main limbs. The first confers jurisdiction over courts to grant applications for temporary injunction, which may be invoked where the Court is satisfied that the ends of justice are at stake. Detailed preconditions which must exist for temporary injunction to issue are provided in Order 37 Rules 1 and 2 (discussed below). The second limb gives power to commit any person in a civil prison if he has disobeyed the court's injunctive order. This enforcement provision makes an order for temporary injunction more meaningful because, otherwise, it could be of no use for courts to issue injunctive orders which are unenforceable.

\section{Order 37 Rule 1}

This Rule lays down alternative preconditions before a court may consider temporary injunctions. The first is where any property, the subject matter of the main suit, is in danger of being wasted, damaged, or

\footnotetext{
Akademischer Austauschdienst (DAAD) scholar at the University of Bremen (Germany). Email: alex.makulilo@out.ac.tz

1 Cap. 33 RE 2002.
} 
alienated by any party to the suit or is likely to suffer loss of value by reason of its continued use by any party to the suit, or wrongly sold in execution of a decree. The second arises where a defendant threatens or intends to remove or dispose of his property with a view to defraud his creditors. In either situation, courts may grant temporary injunctive relief.

\section{Order 37 Rule 2}

This Rule governs temporary injunctions where a defendant breaches a contract or commits any other kind of injury. In contrast with Rule 1, Rule 2 is openended in the sense that it takes care of any other act which is not specified in Rule 1 but which may similarly injure the subject matter of the plaintiff's suit before its determination.

Jurisdiction to issue temporary injunctions is not absolute, being limited where relief is sought against the Government: there the provisos to Order 37 Rules 1 and 2 oust the court's jurisdiction. However, courts may still make declaratory orders as to the rights of the parties.

\section{Principles governing issuance of temporary injunction}

The relevant principles are generally based on the decisions and practices of English law, ${ }^{2}$ the most important being the House of Lords case of American Cyanamid Co. $v$ Ethicon Ltd. ${ }^{3}$ In this case, Lord Diplock laid down three principles which courts must engage in exercising discretionary jurisdiction before issuing or refusing applications for temporary injunction: (i) the application for temporary injunction must reveal a prima facie case with a probability of success; (ii) the applicant must then show that he would suffer an irreparable injury if the temporary injunction is refused; (iii) on the balance of convenience, the applicant must stand to suffer more from the refusal of an order for temporary injunction than that which the respondent would suffer from its grant.

2 Tanzania is a common law jurisdiction. As such, English law provides one of the sources of law: see section 2(3) of the Judicature and Application of Laws Act, Cap. 358 RE 2002. Although this application of the English law is subject to a reception clause, subsequent case law still offers persuasive authority for courts in Tanzania.

3 [1975] AC 396; [1975] 1 ALL ER 504.

4 The term 'East Africa' is limited to the member states of the defunct East African Community-Tanzania, Kenya, and Uganda (all being common law jurisdictions).

5 (1976) KLR 42.

6 (1973) EA 358, p. 360.

7 See CPC International Inc v Zainab Grain Millers Ltd, Civil Appeal No. 49 of 1995, CAT, Dar es Salaam (unreported); Agip (Kenya) Limited $v$
American Cyanamid was received in East Africa $^{4}$ with mixed judicial opinions. In Abel Salim \& Others $v$ Okong'o \& Others, ${ }^{5}$ for example, the defunct Court of Appeal for East Africa (CAEA) expressly rejected it, holding that the conditions for grant of an interlocutory injunction were well settled in East Africa in Giella $v$ Cassman Brown and Co. Ltd. ${ }^{6}$ The conditions there were (i) the probability of success; (ii) irreparable harm which would not be adequately compensated for by damages; and (iii) if in doubt, then a balance of convenience. The Court saw no reason to depart from Giella.

After the CAEA Abel Salim, Giella became an authoritative source for principles of temporary injunction in East Africa. ${ }^{7}$ Although Giella was cited with approval by the Court of Appeal of Tanzania (CAT) in CPC International Inc $v$ Zainab Grain Millers $L t d,{ }^{8}$ for no apparent reasons its principles were never applied by the Court to the facts of that case. In contrast to the acceptance by supreme courts in East African states of the view expressed in Abel Salim on the application of American Cyanamid, the HCT often cited American Cyanamid with approval. For instance, the High Court cited American Cyanamid in CPC International Inc $v$ Zainab Grain Millers Ltd. ${ }^{9}$ However, it is unfortunate that in this case the Court misdirected itself that both American Cyanamid and Giella were decided on the basis of the same principles. Similar faulty reasoning was repeated by the High Court in Suryakant D. Ramji $v$ Savings and Finance Limited and Others ${ }^{10}$ and Gapco Tanzania Limited and Another v Barclays Bank PLC and Another. ${ }^{11}$ However, in N.V. Philips' Gloeilampenfabrieken $v$ Aloyce Ngowi t/a N.M Hardware and Another ${ }^{12}$ the High Court clearly pointed out the distinction between them: while paying attention to Giella the High Court cited American Cyanamid with approval, pointing out its relevance in setting the standard of proving a prima facie case in applications for temporary injunction. As in American Cyanamid, the High Court held that in granting temporary injunction, it is not necessary for a plaintiff to establish the likelihood of success. ${ }^{13}$

Appollos Kennedy Mwangi t/a Appollos Service Station [1996] eKLR; Uganda Performing Rights Society Limited v Fred Mukubira, Misc. Application No. 818 of 2003, High Court of Uganda (Commercial Division), Kampala (unreported).

8 Civil Appeal No. 49 of 1995, CAT, Dar es Salaam (unreported).

9 Civil Case No. 121 of 1993, HCT, Dar es Salaam (unreported).

10 Civil Case No. 30 of 2000, HCT (Commercial Division), Dar es Salaam (unreported).

11 Civil Case No. 117 of 2006, HCT, Dar es Salaam (unreported).

12 Commercial Case No. 38 of 2005, HCT (Commercial division), Dar es Salaam (unreported).

13 ibid, p. 7. 
Although the HCT has repeatedly cited American Cyanamid with approval, the $\mathrm{CAT}^{14}$ has not. However, recently in Kenya, the Court of Appeal has considered the application of American Cyanamid, concluding that it was wrong to consider American Cyanamid as wholly irrelevant in Kenya. ${ }^{15}$ This pronouncement is contrary to the view expressed in Abel Salim by the defunct CAEA and it is an approval of the case in Kenyan jurisdiction.

While the CAT had cited with approval Giella, the pronouncement of the HCT in Attilio $v$ Mbowe $^{16}$ has always been considered the source of legal principles governing issuance of temporary injunction in Tanzania. In Attilio, the High Court laid down three conditions for the temporary injunction to issue: ${ }^{17}$ (i) there must be a serious question to be tried on the facts alleged and a probability that the plaintiff will be entitled to the relief sought; (ii) the court's interference must be necessary to protect the plaintiff from the kind of injury which may be irreparable before his legal right is established; (iii) on the balance, there will be greater hardship and mischief suffered by the plaintiff from the withholding of the injunction than will be suffered by the defendant from the granting of it.

In 1996, the CAT affirmed Attilio in Ravindra Desai \& Another $v C R D B,{ }^{18}$ just 1 year after a similar approval by the Court in Giella. Arguably, though Giella did not expressly cite Attilio, the later case seems to have been inspired by the earlier one. Possibly because Attilio was decided earlier than Giella, it has been more frequently cited by courts in Tanzania as the authority for issuance of temporary injunction than Giella.

In 2005, the HCT observed that Attilio was static in that it did not well address the issue of 'probability of success' in the first principle governing temporary injunction. ${ }^{19}$ To correct this mischief, the High Court adopted the approach in American Cyanamid. ${ }^{20}$ Since a decision of a judge of the HCT does not bind another judge of the same court, the HCT has continued to harbour divergent opinions, which are considered below.

14 The CAT is the supreme court in the United Republic of Tanzania (Tanzania mainland and Zanzibar).

15 See Wairimu Mureithi v City Council of Nairobi, Civil Appeal No. 5 of 1979, Court of Appeal of Kenya, Nairobi (unreported).

16 [1969] HCD 284.

17 ibid, p. 216.

18 Civil Reference Nos 2 and 3 of 1996, CAT, Dar es Salaam (unreported).

19 N.V. Philips' Gloeilampenfabrieken v Aloyce Ngowi t/a N.M Hardware and Another Commercial Case No. 38 of 2005, HCT (Commercial Division), Dar es Salaam (unreported), p. 6

20 See footnote 4 above.

21 American Cyanamid Co. v Ethicon Ltd [1975] AC 396; [1975] 1 ALL ER 504, p. 510; see also, J Leubsdorf, 'Preliminary Injunctions: In Defence of

\section{Prima facie case}

Some courts have interpreted prima facie case with a probability of success to mean a 'serious question to be tried. ${ }^{21}$ This is deemed to have been made out if an applicant demonstrates a 'serious question to be tried'. What is meant by 'a serious question' is any question which is not 'frivolous or vexatious'. It is not necessary for the applicant to demonstrate 'a probability of success' at the trial. The rationale for this legal position, said Lord Diplock, was that:

It is no part of the court's function at this stage of the litigation to try and resolve conflicts of evidence on affidavit as to facts on which claims of either party may ultimately depend nor to decide difficult questions of law which call for detailed argument and mature considerations. These are matters to be dealt with in the trial. ${ }^{22}$

Similar reasoning was followed in Lian Keow Sdn Bhd $v$ Overseas Credit Finance $B h d^{23}$ where His Lordship Abbas observed that an interlocutory injunction is a temporary and discretionary remedy. Considering whether to grant it, the court is not concerned with the chances of success of the appellants in proving their civil suit at the forthcoming trial; neither is the court's function to evaluate the evidence and materials before it for that purpose. The court is simply concerned with what it has to do in the meantime in order to protect the right of the parties so that no irreparable injury would be caused to either of them. Further, the court must be satisfied that there are serious questions to be gone into in that suit, lest an application for an injunction should be made on frivolous and vexatious grounds. This line of judicial opinion is noticeable in some holdings of the HCT, more particularly Philips. ${ }^{24}$

In contrast, some courts have gone further, considering not only the existence of a 'serious question to be tried' but also the relative strengths of the parties' claims. In England, this principle was laid down by the High Court in Series 5 Software, ${ }^{25}$ where Laddie J treated a 'probability of success' as a separate and dis-

the Merits', the Social Science Research Network Electronic Paper Collection: http://ssrn.com/abstract=954733, p. 14 where the learned author observes that in American Cyanamid, the House of Lords held that, once the plaintiff demonstrates that there is a serious question to be tried, the merits should not be further considered and the decision should be based on the balance of convenience.

22 ibid.

23 [1982] 2 MLJ 162; see also Minesota Mining \& Manufacturing Co. v Shah and Shah, HCCC No. 3446 of 1980; R Kuloba, Principles of Injunctions (Oxford University Press, Nairobi, 1987), p. 49.

24 See footnote 13 , above.

25 (1996) CLC 63. 
tinct criterion to the prima facie case. This approach is also noticeable in the most recent Tanzanian case of Isaya Mwakilasa@Wakuvanga and Nine Othersv East Africa Television Ltd and Two Others ${ }^{26}$ (the 'ZE COMEDY' case).

\section{Irreparable injury}

This is the second condition which requires the applicant to show that, unless the defendant's activity or omission is made subject to the control or direction of an injunction, his position will in some way be changed for the worse: that he will suffer damage as a consequence of the plaintiff's act or omission complained of. ${ }^{27}$ By 'damage', it has been stressed that the defendant's actions are regarded not from the legal point of view as being violations of a right, but simply as a possible source of harmful practical consequences to the applicant. ${ }^{28}$ Moreover, the applicant has to demonstrate that the contemplated damage is not capable of being compensated by way of damages.

\section{Balance of convenience}

This principle requires the court to establish that the balance of convenience in the event of withholding the relief of temporary injunction will, in all events, exceed that of the defendant who is restrained. ${ }^{29}$

\section{Interaction between general principles of temporary injunction and trade mark infringement}

The purpose of temporary injunction is to preserve the status quo pending the main suit. In the context of trade mark disputes, the main cause of action generally is infringement or passing-off of goods or services, or both. Accordingly where a party seeks temporary relief in trade mark disputes, he does so in order to restrain an ongoing or imminent infringement. Similarly, maintenance of the status quo also assists a plaintiff who succeeds in the main suit.

Consumer confusion is the yardstick of trade mark infringement in Tanzanian law. Such confusion is pre-

26 Commercial Case No. 46 of 2008, HCT (Commercial Division), Dar es Salaam (unreported).

27 Kuloba, Op cit, p. 50.

28 ibid.

29 BM Prasad, Mulla, The Code of Civil Procedure (Butterworths, New Delhi, 17th edn, vol. 4, 2007), p. 265.

30 See eg C.P.C International Inc. v Zainabu Grain Millers Ltd, Civil Case No. 121 of 1993, HCT, Dar es Salaam (unreported), p. 15.

31 See, for example, C.P.C International Inc. $v$ Zainabu Grain Millers Ltd, Civil Appeal No. 47 of 1995, CAT, Dar es Salaam (unreported), p. 7; Colgate Palmolive Company v Zakaria Provision Stores and 3 Others, Civil sumed when the trade mark used by the alleged infringer is identical to that of a trade mark owner, as applied to identical goods or services. Identity or similarity as such is not, however, determinative of trade mark infringement since on the facts no confusion may arise.

Analysis of trade mark infringement addresses three main principles. First, one must investigate whether the trade marks are identical or similar. One next asks whether such trade marks have been used in relation to identical or similar goods or services. Finally, is the identity or similarity between the trade marks likely to cause confusion to consumers as to the source of origin of goods or services?

From this analysis, it can be argued that the first and second principles governing trade mark infringement are determinants of the first principle of temporary injunction, the prima facie case. This is so because where trade marks are identical or similar and have been applied to identical or similar goods or services, there is a strongly arguable case of trade mark infringement. Unless there are other reasons which may affect a finding of likelihood of confusion, a plaintiff is likely to succeed in the main suit. The temporary injunction should therefore issue where trade marks and goods or services upon which such marks are applied are identical or similar, unless on account of irreparable injury or balance of convenience the court finds in favour of a defendant.

\section{High Court case law}

The most challenging issue broached by the High Court's decisions lies on the interpretation of the first principle. As previously mentioned, the scope of this principle is still uncertain. As a result, the HCT is split into two schools of thought. One believes that prima facie case with a probability of success must be construed as a 'serious question to be tried', ${ }^{30}$ the issue of 'probability of success' being irrelevant since it leads to prejudging the merits of the case. The other sees the principle as having two distinct criteria: ${ }^{31}$ (i) prima facie case and (ii) 'probability of success'. The former is

Case No. 1 of 1997, HCT, Dar es Salaam (unreported), p. 2; Tanzania Breweries Ltd $v$ Kibo Breweries Ltd and Kenya Breweries Ltd, Civil case No. 34 of 1999, HCT, Dar es Salaam (unreported), p. 5; Glaxo Group Limited $v$ Agri-Vet Limited, Commercial Case No. 73 of 2002, HCT (Commercial Division), Dar es Salaam (unreported), p. 9; Agro Processing and Allied Products Limited $v$ Said Salim Bakhresa \& Co. Ltd, Commercial Case No. 31 of 2004, HCT (Commercial Division), Dar es Salaam (unreported), p. 3; Tanzania Cigarette Tobacco Co. Limited v Iringa Tobacco Co. Limited, Commercial Case No. 12 of 2005, HCT (Commercial Division), Dar es Salaam (unreported), p. 6; and Isaya Mwakilasa@Wakuvanga and Nine Others v East Africa Television Ltd and Two Others, Commercial Case No. 
construed similarly to the first school of thought, while the latter refers to the relative strength of a case.

In Philips, ${ }^{32}$ the HCT reformulated the first principle of temporary injunction somewhat confusingly. The High Court, while citing Attilio, erroneously stated that an applicant has first to show that 'there are serious questions to be determined by the court' and that a prima facie case has been established. ${ }^{33}$ Here the criteria are a 'serious question to be tried' and a prima facie case. The High Court did not further explain what is meant by prima facie case. It is doubtful if prima facie case in this formulation also means a 'serious question to be tried'. This is because a 'serious question to be tried', which stands for prima facie case in the first and second schools of thought, is the first criterion of the principle in this formulation while 'probability of success' is the second. While the High Court restated this principle as in the first school of thought, ${ }^{34}$ it is arguable that the two formulations create further uncertainties in the Court's jurisprudence.

\section{Ordinarily, the standard of proof in a civil case is the 'balance of probability'. This requires a plaintiff to establish his case beyond 50 per cent}

Another issue that has become a subject of controversy in the High Court's jurisprudence is the required standard of proof of prima facie case with a probability of success. Ordinarily, the standard of proof in a civil case is the 'balance of probability'. This requires a plaintiff to establish his case beyond 50 per cent. ${ }^{35}$ The question is whether a proof of prima facie case with a probability of success must pass the 'balance of probability' test.

The earliest High Court holdings, illustrated by C.P.C International Inc. $v$ Zainabu Grain Millers Ltd, ${ }^{36}$ addressed very diffusely the issue of standard of proof in temporary injunctions. In this case, for example, the Court pointed out that the burden of satisfying the Court that there has been trade mark infringement or passing-off rests upon the plaintiff. ${ }^{37}$ To discharge this

46 of 2008, HCT (Commercial Division), Dar es Salaam (unreported), p. 4.

32 Commercial Case No. 38 of 2005, HCT (Commercial division), Dar es Salaam (unreported).

33 ibid, p. 2.

34 See p. 7 of the High Court's holding in Philips.

35 By contrast, in criminal proceedings, the prosecution must prove its case beyond reasonable doubt-a higher standard than 'balance of probability'. burden, it is sufficient if the plaintiff can show that there is an arguable case against the defendant. ${ }^{38}$ Moreover, the plaintiff must show that continuance of the defendant's activities until the trial is likely to cause substantial damage to him which is irreparable in the sense that it will not be compensated by an order for damages at the trial. ${ }^{39}$ Applying this standard, his Lordship Mwaikasu held that the application for an interlocutory injunction failed because the plaintiff did not prove both infringement and passing-off.

An analysis of C.P.C International reveals contradictions which arise from the Court's treatment of the principles for temporary injunction within the context of trade mark infringement and passing-off, since the Court abandoned application of the principles of temporary injunction and engaged the likelihood of confusion test, the test for trade mark infringement. The latter test attracts proof to a 'balance of probability' which is applicable in the main suit.

When C.P.C International went on appeal, the CAT ${ }^{40}$ found two errors in the decision. First, the judge erred in law in determining the application for temporary injunction by deciding issues which should have been resolved and determined at the trial of the main suit. Second, he misdirected himself on the principles relating to the grant of temporary injunction.

Addressing the first issue, Lubuva, J.A, held that the trial judge exceeded the scope necessary for determination of interim injunctions, ${ }^{41}$ observing that, in dealing with the proceedings for an interlocutory injunction, the judge was in effect trying the main suit, at a stage which had not been reached.

As regards the second issue, the Court of Appeal held that, in all cases involving the grant of temporary injunctions, the applicable principles are the same. In the light of these principles, what was expected of the judge was to consider whether, on the facts as disclosed from affidavits and pleadings, a prima facie case had been shown: it was thus premature for him to require the appellant to prove infringement or passing-off. After setting aside the ruling and order of the lower court, the Court of Appeal granted the application for temporary injunction as a matter of course and without consideration of the principles governing

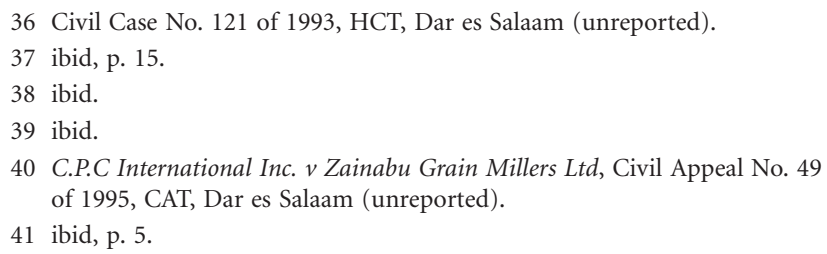


temporary injunction. One would have expected the Court to reconsider the application in the light of the principles for issuance of temporary injunction. However, this was not the case.

In Colgate Palmolive, ${ }^{42}$ the High Court stated that the prima facie rule does not require that the Court should examine the material before it closely and come to a conclusion that the plaintiff has a case in which he is likely to succeed, for to do so would amount to prejudging the case on its merits. ${ }^{43}$ The effect of this holding is that it lowers the standard of proof in temporary injunctions below the 'balance of probability' standard. Although in this case the Court granted temporary relief, its analysis shifted to assessment of trade mark infringement. For example, having found that there were similarities between the appearance of COLGATE and ABC Dent products, the High Court held that there was a real likelihood of confusion of consumers. ${ }^{44}$ Arguably, assessment of confusion entails an engagement of the likelihood of confusion test. Similarly, determination of likelihood of confusion requires that a plaintiff proves his case on a 'balance of probability'.

In Colgate Palmolive, the HCT also laid down the test for similarities between contested trade marks: one must compare the whole of the plaintiff's mark and get-up with the whole of the defendant's mark and get-up to see whether there are similarities which go to create or show the prospects of confusion and actual deception

In Colgate Palmolive, the HCT also laid down the test for similarities between contested trade marks: one must compare the whole of the plaintiff's mark and get-up with the whole of the defendant's mark and getup to see whether there are similarities which go to create or show the prospects of confusion and actual deception. ${ }^{45}$ As to the standard of proof of such similarities, this is a consumer of average intelligence with an imperfect recollection. ${ }^{46}$ Subsequently, in Tanzania Breweries Ltd $v$ Kibo Breweries Ltd and Kenya Breweries

\footnotetext{
42 Civil Case No. 1 of 1997, HCT, Dar es Salaam (unreported).

43 ibid, p. 2.

44 ibid, p. 3.

45 ibid, p. 3.

46 ibid.

47 Civil Case No. 34 of 1999, HCT, Dar es Salaam (unreported).

48 ibid, p. 8.
}

Ltd, ${ }^{47}$ Justice Kalegeya expressed strong disagreement with Justice Mapigano as to the standard of proof of similarity. Justice Kalegeya's reasoning was that here one deals with an increasingly poor recollection in an ordinary person with the progressive consumption of the product. ${ }^{48}$ In contrast, the learned judge held that the Court has to wear the shoes of a 'common man', spread the two marks before it, and ask itself whether there are resemblances between the two which would make it pick a product which was not intended but the opposite. ${ }^{49}$ In a course of its finding, the High Court shifted its analysis from a 'common man' standard to a 'common beer consumer' and finally to an 'ordinary person'.

Unsurprisingly, the Court failed to analyse systematically the terms 'common man', 'common beer consumer', and 'ordinary person'. An immediate question which arises here is whether these terminologies refer to the same standard and are thus synonymous. Arguably, they are not. In a regulatory context, the terms 'common man' and 'ordinary person' as referred in Tanzania Breweries suggest cognitive ability as opposed to the 'common beer consumer' which makes reference to a relevant market for a product for which contested trade marks are used. In our context, this is specifically a beer market. However, where the products and services are widely prevalent so that everybody purchases them, the relevant market can be equated with the population at large. ${ }^{50}$ The rationale in favour of the imperfect recollection standard emanates from the impossibility of perfect recall of the product a consumer purchases. And where competing goods are not sold side-by-side, the consumer has no chance to inspect the trade marks closely.

In Tanzania Breweries, the HCT also expressed the difficulty of proving a prima facie case at a stage when no evidence has yet been adduced. ${ }^{51}$ The apparent acceptance that no evidence is required at the interlocutory stage is erroneous, because Order 37 Rule 1 explicitly requires support by affidavit or otherwise. The proper question may be what amount of evidence is required to prove temporary injunction? However, notwithstanding this difficulty, the HCT granted temporary injunction in Kibo Match Group Limited v Mohamed Enterprises (T) Limited $^{52}$ as a matter of course and without any thoughtful analysis. Both Tanzania

\footnotetext{
49 ibid.

50 J Phillips, Trade Mark Law: A Practical Anatomy (Oxford University Press, New York, 2003), p. 353.

51 Tanzania Breweries Ltd $v$ Kibo Breweries Ltd and Kenya Breweries Ltd, Civil Case No. 1 of 1997, HCT, Dar es Salaam (unreported), p. 6.

52 Civil case No. 6 of 1999, HCT (Commercial Division), Dar es Salaam (unreported).
} 
Breweries and Kibo Match were decided by the same judge, so one would have expected more consistency.

In Kibo Match, an action for trade mark infringement, the plaintiff, proprietor of the KANGAROO trade mark for matchboxes it sold, objected to the importation and sale by the defendant of match boxes bearing the identical trade mark. The plaintiff sought interim relief. In granting a temporary injunction, finding for the plaintiff on the prima facie case principle, the High Court considered three factors:

(i) The plaintiff's registered trade mark was prima facie valid. (The Court avoided comment on the defendant's evidence that it commenced importation of KANGAROO matchboxes the year before the plaintiff's registration, as was its submission that the registration had expired.) Arguably, it was an error on the part of the Court to grant temporary injunction while the validity of the plaintiff's trade mark was itself in issue. This argument is supported by the High Court's own holding in Tanzania Cigarette Company Limited v Mastermind Tobacco (T) Limited, ${ }^{53}$ where Justice Massati was prepared to hold that a proprietor of an unregistered trade mark has the right to prevent others from using an identical or similar trade mark through an action of tort of passing-off. ${ }^{54}$ Stated differently, a registered trade mark does not override a prior right of use of an unregistered trade mark merely because the former is registered. Defence counsel, however, failed to raise such counter-claim.

(ii) The plaintiff's use of the trade mark is taken into consideration. However, the Court did not consider the defendant's prior use of the trade mark in question.

(iii) Is the defence based on the merits or on technical grounds? In the Court's opinion, the latter amounts to an admission of the allegations. This may be erroneous. A temporary injunction is a discretionary remedy, granted only after the Court is satisfied that there are compelling reasons for it. The fact that a defendant has not challenged the merit of an application, or has even failed to appear on the day of hearing, are not such compelling reasons. The Court also confused the rules on pleadings with counsels' submissions. In the former, a defendant's admission of the plaintiff's

53 Commercial Case No. 11 of 2005, HCT (Commercial Division), Dar es Salaam (unreported).

54 ibid, pp. 38-40; see also, section 30 of the Trade and Service Marks Act, Cap. 326 RE 2002. allegations is deemed the moment he does not traverse any of the allegations in the plaint or, the defendant has totally failed to file a written statement of defence. The High Court mistakenly extended the rule on defendant's admission in pleadings to counsel's submission.

Consistent with Tanzania Breweries was the Court's holding in Glaxo Group Limited $v$ Agri-Vet Limited. ${ }^{55}$ There the plaintiff sued for trade mark infringement and passing-off, alleging that it was a registered proprietor of the trade mark COFTA which it used on cough and cold tablets. Subsequently, the defendant registered a trade mark COFEX and began selling the same tablets as the plaintiff, using similar trade dress. Before trial, the plaintiff sought to restrain the defendant from trading in this fashion pending the trial.

In his decision, Justice Kalegeya made two important statements. As these statements have been repeatedly approved in subsequent HCT decisions, I reproduce them verbatim. The first reiterated the difficulty in establishing prima facie case with a probability of success and also set the standard of proof:

I should outrightly observe that this is the trickiest principle among the three upon which the court has to exercise great care before making a finding. Why? As I had an occasion to observe in Commercial case No.5 of 1999, Tanzania Tea Packers Ltd $v$ The Commissioner of Income Tax and Another, "...although Attilio case shows that there should exist a probability of applicant's success in the main matter, in my view, this should not be interpreted to mean that the facts at hand should declare the applicant a winner. To conclude as such would be to pre-empt the trial and would militate against the basic principles of justice. It will be tantamount to pre-judging parties before they are heard on the controversy. In my view therefore, what is meant is that the applicant should show that though evidence has not been given, the allegations so far made by him, prima facie, portray him as having been aggrieved by the respondent entitling him to the reliefs being sought in the main suit." ${ }^{35}$

The second removed any possibility for the plaintiff to prove the first principle of temporary injunction:

My views are that in conflicts of trade marks and business names, temporary injunctions should very sparingly be sought by parties and granted by courts because of the intricacy surrounding the first principle of establishment of a prima facie case with a probability of success. I am saying so because I fail to see how the plaintiff/applicant

55 Commercial Case No. 73 of 2002 HCT (Commercial Division), Dar es Salaam (unreported).

56 ibid, p. 10. 
can establish a prima facie case with a probability of success without going into details of what he alleges to be passingoffs or infringement and in turn without the court analysing what is submitted and being of those allegations. ${ }^{57}$

These two statements demonstrate an enormous contradiction in the learned judge's observations. In the first statement, the learned judge attempted to keep the threshold for proof of prima facie case with a probability of success at a minimum level, which logically implies that an applicant may easily meet the legal test. Yet in his second statement, the learned judge raised the standard of proof too high. In fact, he effectively abolished interim injunctive relief for trade mark infringement and passing-off when he stressed that there is no possibility for an applicant of temporary injunction to establish a prima facie case with a probability of success without going into details of what is alleged to be passing-off or infringement.

$$
\begin{aligned}
& \text { It is arguable that similarity between trade marks } \\
& \text { is the most important factor to which the High } \\
& \text { Court has to pay considerable weight in assessing } \\
& \text { whether a prima facie case is established }
\end{aligned}
$$

Moreover in both Tanzania Breweries and Glaxo Group, the High Court ignored the fact that contested trade marks were similar or dissimilar. Thus in Tanzania Breweries, the High Court found that the contested trade marks were dissimilar. However, this was the basis for the Court's refusal to find that prima facie case with a probability of success had been established. Later in the Glaxo Group, the Court found that there were similarities between the marks, yet the Court did not find the plaintiff to have successfully established prima facie case with a probability of success. It is arguable that similarity between trade marks is the most important factor to which the High Court has to pay considerable weight in assessing whether a prima facie case is established.

The reluctance to grant temporary injunction in Tanzania Breweries and Glaxo Group was extended in

\footnotetext{
57 ibid, p. 14.

58 Commercial Case No. 31 of 2004 HCT (Commercial Division), Dar es Salaam (unreported).

59 ibid, p. 6.

60 Commercial Case No. 12 of 2005 HCT (Commercial Division), Dar es Salaam (unreported).

61 In Pianotist's Application (1906) 23 RPC 774 at 777, J Parker laid down a principle in comparison of word trade marks as follows. 'You must take the two words. You must judge of them, both by their look and by their sound. You must consider the goods to which they are to be applied. You
}

Agro Processing. ${ }^{58}$ There the complaint was that the defendant was passing off goods by using the word POA, the plaintiff's trade mark. To protect the status $q u o$, the plaintiff sought to restrain the defendant from using the word POA in labelling, advertising, selling, distributing, circulating, or otherwise, in relation to food flour milled, packed, sold, distributed, circulated, or otherwise by the defendant. Refusing the plaintiff's application, the High Court held that it is extremely difficult to determine whether a prima facie case exists in this case without going to the merits. ${ }^{59}$ The Court cited with approval the Glaxo Group.

Glaxo Group was further extended in Tanzania Tobacco Co. Limited v Iringa Tobacco Co. Limited, ${ }^{60}$ where the plaintiff alleged that the defendant was trading in trade marks closely similar and resembling the plaintiff's marks. Both parties had registered their trade marks for cigarettes. Refusing temporary relief, the High Court reiterated the difficulty of establishing a prima facie case, citing Glaxo Group and Agro Processing. Said the Court, this application was unsuitable for an order of temporary injunction since it would be difficult to lay demarcation lines between matters to be considered for temporary relief without prejudging the main suit.

The High Court equated the facts in Agro Processing with those of Tanzania Tobacco, possibly a reason why the Court followed that case. Surprisingly, the High Court was silent on how the facts in Agro Processing were similar to Tanzania Tobacco for, in Agro Processing, the word trade mark POA was in dispute by the contending parties, while in Tanzania Tobacco the dispute centred on colour arrangement, get-ups, and size of the logos. It is difficult to comprehend how the Court was able to equate the facts of the two cases, one involving conceptual similarity and the other visual similarity, where the criteria for comparison are different. ${ }^{61}$

After Tanzania Tobacco, the High Court decided Philips. Unlike previous cases, Philips discussed clearly the relevance of American Cyanamid in the Tanzanian legal system. The most important point raised in this holding is that the proof of 'probability of success' as required in Attilio was unnecessary. However, Philips has its shortcomings. First, although Justice Massati must consider the nature and kind of customer who would be likely to buy those goods. In fact, you must consider all the circumstances; and you must further consider what is likely to happen if each of those trade marks is used in a normal way as a trade mark for the goods of the respective owners of marks.' Later in Sabel v Puma, Case C-251/95 [1995] ETMR 1, the European Court of Justice held that the comparison of trade marks should involve a global appreciation of the visual, aural, or conceptual similarity of the marks in question, bearing in mind, in particular, their distinctive and dominant components. 
cited some earlier cases, he failed to distinguish their facts from those in Philips. He held that Tanzania Tobacco was distinguishable from Philips, but no factual distinctions between the two cases were drawn. Moreover, the High Court did not comment on other decisions cited by the parties.

Although the High Court granted temporary relief in Philips, it failed to provide thorough analysis of the first principle of temporary injunction. Let us reproduce the observations of the Court verbatim:

Applying those principles in the present case and going through ...the Applicant's affidavit and...the counteraffidavit I am satisfied that the Applicant has managed to establish an arguable case of infringement. ${ }^{62}$

The Court then observed:

There is also no dispute that the Applicant is the registered owner of the trade mark PHILIPS and since courts are here to enforce the provisions of the law I am also satisfied that the Court's interference is necessary, not only to protect the plaintiff from irreparable injury but also to enforce the law.

It is arguable that a mere statement, ' . . . going through ... the Applicant's affidavit and ... the counter-affidavit I am satisfied that the Applicant has managed to establish an arguable case of infringement', does not suffice to clearly show what the learned judge had considered to find existence of an arguable case of infringement. The judge was supposed to synthesize the contentious facts disclosed in the affidavit and counter-affidavit within the principles of temporary injunction. Undoubtedly, this analysis had remained in the judge's mind, as his ruling does not contain any line of reasoning towards his conclusion. There is therefore an apparent disconnection between the stated law and its application in the case.

Similarly, the High Court has apparently taken into account that the applicant was a registered owner of the trade mark PHILIPS. While it is admitted that registration creates a presumption as to the validity of ownership, ${ }^{63}$ registration as such is insufficient to constitute an arguable case of infringement since even the proprietor of an unregistered trade mark may sue a proprietor of a registered trade mark for passing-off. ${ }^{64}$ This view was expressed by Massati J himself in Tanzania Cigarette Company Limited $v$ Mastermind Tobacco (T) Limited $^{65}$ It is surprising that the holding in Tanzania Cigarette contradicts Philips. In Tanzania

62 ibid, p. 8.

63 See section 50(1) of the Trade and Service marks Act, Cap. 326 RE 2002. 64 ibid, section 30 .
Cigarette, Massati J was prepared to hold that, where an application for trade mark used by a proprietor is pending with the registrar and a subsequent trade mark becomes registered while the earlier application is still pending, such registered trade mark does not override the prior rights of use of the pending application. The learned judge then went so far as to deem such pending application a trade mark already in the register. However, section 32(4) of the Trade and Service Marks Act clearly provides that the exclusive right of use conferred on a registered trade mark in section 31 of the Trade and Service Marks shall not be deemed to be infringed where two or more registered trade marks are identical or nearly resemble each other. It is therefore erroneous to accept registration of the applicant's trade mark as evidence of an arguable case of infringement without considering the defendant's title.

Isaya Mwakilasa is the latest High Court decision.
There, the Court reiterated its position in the
Glaxo Group and Agro Processing

Isaya Mwakilasa ${ }^{66}$ is the latest High Court decision. There, the Court reiterated its position in the Glaxo Group and Agro Processing. In brief, the plaintiffs were comedians performing under the auspice of East Africa Television Ltd, the first defendant. Throughout, the plaintiffs used the name ZE COMEDY with permission from the National Arts Council of Tanzania. This permit was for 1 year. Subsequently, the first defendant applied to register a trade mark ZE COMEDY with the second defendant, the Registrar of Trade and Service Marks. This application was still pending. After expiry of their contract with the first defendant, the plaintiffs entered a new contract with Tanzania Broadcasting Corporation to air their performances using the same trade name, ZE COMEDY. This was disputed by the first defendant, as well as the second and third defendants as regulatory bodies. Before trial, the plaintiffs sought orders for temporary injunction against the defendants to restrain them from interfering, disturbing, and preventing them from conducting their business in the name and design known as ZE COMEDY pending hearing of the suit. In a 26-page ruling, the HCT (Madame Justice Oriyo) extensively

\footnotetext{
65 Commercial Case No. 11 of 2005 HCT (Commercial Division), Dar es Salaam (unreported).

66 See footnote 28 , above.
} 
dealt with one issue: had the plaintiffs/applicants established a prima facie case with a probability of success?

The High Court held that there were triable issues. ${ }^{67}$ However, the chances of the plaintiff succeeding were non-existent. ${ }^{68}$ The Court's reasoning was based on the fact that, since no status quo was in existence at the time of institution of the suit, no temporary injunction could issue. Let us consider the Court's analysis.

The Court found that when the suit was filed, neither the plaintiffs nor the first defendant were using the mark ZE COMEDY. Hence neither the applicants nor the first respondent had exclusive right of use or protection. When the present suit was filed, the first respondent had applied to be registered as owner of the trade mark, ZE COMEDY. However, such application was still under the registration process with the second respondent. Meanwhile, the applicants had a permit to perform as ZE COMEDY PRODUCTION from the National Arts Council. This permit was for 12 months, but had expired a month earlier. There was therefore no status quo on the date of institution of the action which was worthy of preservation by the injunction.

The Court's reasoning was based on the fact that,
since no status quo was in existence at the time
of institution of the suit, no temporary injunction
could issue.

Two issues must be considered here. First, what is the status of a pending registration for a trade mark? Second, what is the status of an expired name registered under the National Arts Council Act in the context of the Trade and Service Marks Act? In Tanzania Cigarette, the High Court stretched the definition of the term 'already in the register' in section

\footnotetext{
67 ibid, p. 13.

68 ibid.

69 Cap. 326 RE 2002.

70 Section 20(1) of the Trade and Service Marks Act, Cap. 326 RE 2002: 'Subject to the provisions of subsection (2) trade or service mark cannot be validly registered in respect of any goods or services if it is identical with a trade or service mark belonging to a different proprietor and already on the register in respect of the same goods or services or closely related goods or services or that so nearly resembles that a trade or service mark as to be likely to deceive or cause confusion.'

71 Section 28(1) of the Trade and Service Marks Act, Cap. 326 RE 2002: 'When an application for registration of a trade or service mark has been accepted under either(a) the application has not been opposed and the time of opposition has expired; or (b) the application has been opposed and the opposition has been decided in favour of the applicant, the Registrar shall, unless the application has been accepted in error, register
}

20(1) of the Trade and Service Marks Act ${ }^{69}$ to include trade marks of which the registration was pending with the Registrar. ${ }^{70}$ The rationale for this is to afford protection on pending applications which might otherwise be superseded by registration of identical or similar trade marks by a competitor. This would also make section 28 of the Trade and Service Marks Act with respect to the date of registration of a trade mark meaningful. ${ }^{71}$ This being the case then, it is arguable that the status quo of the first defendant at the time of institution of the suit was that the first defendant was deemed to be already in the register as against any competing interest. Hence the High Court's holding was wrong.

What, next, was the status of the plaintiffs after expiry of their 12-month permit from the National Arts Council to perform as ZE COMEDY PRODUCTION? Does such expiry relinquish the plaintiffs' prior rights of use over the name ZE COMEDY PRODUCTION? What could be the position if the plaintiffs did not at all register their group with the National Arts Council as ZE COMEDY PRODUCTION? These questions were not considered by the Court.

While the plaintiffs registered ZE COMEDY PRODUCTION under the National Arts Council Act, ${ }^{72}$ this did not constitute a registered trade mark under the Trade and Service Marks Act. However, such registration could qualify as an unregistered trade mark because it was actually used by the plaintiffs. The expiry of the permit therefore could not affect this status because, even if the plaintiffs had not registered their group by the National Arts Council but actually used the name ZE COMEDY PRODUCTION, that could be sufficient to acquire protection under section 30 of the Trade and Service Marks Act. Even if ZE COMEDY PRODUCTION was a registered trade mark, its expiry could not have automatically relinquished the plaintiffs' prior right of use. $^{73}$ Accordingly, the first defendant's act of apply-

the trade or service mark, and the trade or service mark, when registered, shall be registered as of the date on which the application for registration was received, and that date shall be deemed, for the purposes of this Act, to be the date of registration.'

72 Cap. 204 RE 2002.

73 Section 29(1) of the Trade and Service Marks Act, Cap. 326 RE 2002: 'the registration of a trade or service mark shall be for the period of seven years from the date of registration but may be renewed from time to time in accordance with the provisions of this section.' Further in section 29(4) of the same Act it is provided that 'Where the registration of a trade or service mark has expired through non-payment of the fee for renewal or otherwise, that trade or service mark shall nevertheless, for the purpose of any application for registration of a trade or service mark during the year following the date of expiration, be deemed to be a trade or service mark that is already on the register...' See also D Ngassa 'A Short Guide to Trademark Law in Tanzania and Zanzibar' http://www. 
ing to register ZE COMEDY PRODUCTION as a trade mark could not affect the plaintiffs' prior right of use. The High Court was accordingly also wrong as regards the status quo of the plaintiffs at the time of the institution of the suit.

The High Court considered a further reason in refusing the plaintiffs' application: there were similarities between the application for temporary injunction and the plaintiffs' prayers in the plaint. ${ }^{74}$ Arguably, the High Court went too far. First, the prayers in the application and main suit are distinguishable. In the application, the plaintiffs prayed for an order of temporary injunction to restrain the defendants from interfering, disturbing, and/or preventing the plaintiffs from conducting their business in the name and design as ZE COMEDY pending hearing of the main suit. ${ }^{75}$ However, the main prayer in the main suit is permanent and perpetual injunction restraining the first defendant from interfering with the business of the plaintiffs in any manner. ${ }^{76}$ Second, similarities or differences in the prayers in the application for temporary injunction and those in the main suit do not fall in any of the conditions or principles governing temporary injunction.

\section{Marked reluctance}

An overview of the jurisprudence of the HCT indicates that the Court has been reluctant to grant applications for temporary injunction in trade mark infringement disputes. The justification for this reluctance is that it is impossible for a plaintiff to satisfy the prima facie case with a probability of success without crossing into the merits of the main suit. At the same time, it has been difficult for the Court to determine whether a plaintiff has met the requirement of the first principle without touching the merits of the suit.

However, the High Court had granted temporary injunction in Colgate Palmolive, Kibo Match, and Philips. In Colgate Palmolive, the Court considered two factors namely, similarity and likelihood of confusion while in Kibo Match it took into account the fact that the plaintiff was a registered proprietor of the trade mark in issue. In Philips, no reason was disclosed. In C.P.C International, the CAT granted temporary injunction as a matter of course after a refusal by the High Court. The Court did not consider the application in any of the principles of temporary injunction.

It is clear that there are problems with the High Court's jurisprudence. The Court has often considered extraneous factors in granting or refusing interim injunctive reliefs. I argue that in trade mark infringement disputes prima facie case may be satisfied the moment the Court finds that contested trade marks are similar. The rationale for this interpretation is that where trade marks are similar, an arguable case for infringement is established. The Court should not go so far as to consider whether such similarity may likely cause confusion to consumers. The reason is that likelihood of confusion is the test for trade mark infringement. lexglobelaw.com/assets/guide_trade mark2.pdf (accessed on 27 December 2009).

74 See Isaya Mwakilas's ruling (above) p. 21.
75 ibid, p. 2.

76 ibid, pp. 21-22. 